\title{
Transatlantica
}

Revue d'études américaines. American Studies Journal

1 | 2020

Conjunctions of the Literary and the Philosophical in Twentieth- and Twenty-First-Century American Writing

\section{An Interview with Jeffrey Eugenides}

Jérémy Potier

\section{(2) OpenEdition}

Journals

Electronic version

URL: https://journals.openedition.org/transatlantica/15228

DOI: $10.4000 /$ transatlantica. 15228

ISSN: $1765-2766$

Publisher

Association française d'Etudes Américaines (AFEA)

\section{Electronic reference}

Jérémy Potier, "An Interview with Jeffrey Eugenides", Transatlantica [Online], 1 | 2020, Online since 01 December 2020, connection on 31 January 2023. URL: http://journals.openedition.org/transatlantica/ 15228 ; DOI: https://doi.org/10.4000/transatlantica.15228

This text was automatically generated on 31 January 2023.

\section{(c) (1) () $\Theta$}

Creative Commons - Attribution-NonCommercial-NoDerivatives 4.0 International - CC BY-NC-ND 4.0 https://creativecommons.org/licenses/by-nc-nd/4.0/ 


\section{An Interview with Jeffrey Eugenides}

\section{Jérémy Potier}

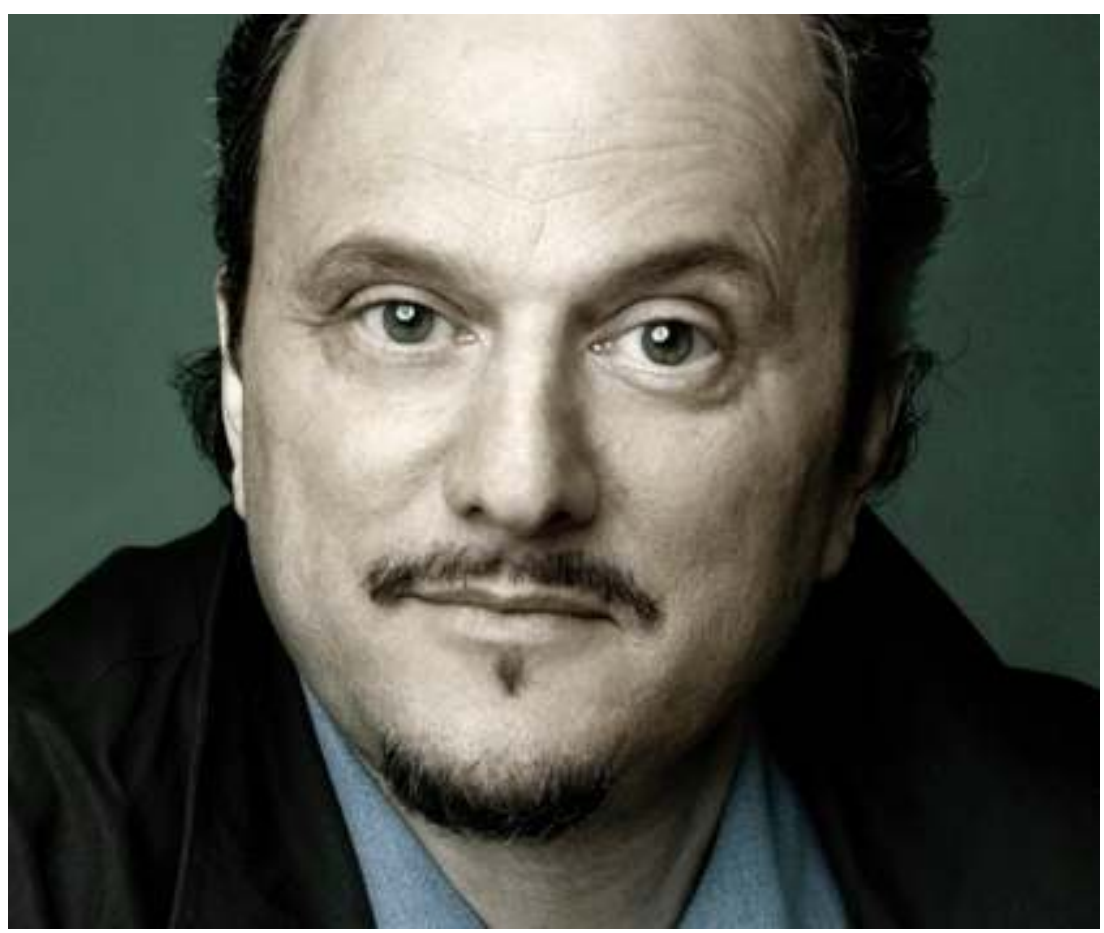

(C) Gaspar Tringale

1 Jeffrey Eugenides's debut novel, The Virgin Suicides, was published to major critical and popular acclaim in 1993. It has since been translated into thirty-four languages and adapted on screen by Sofia Coppola. His second novel, Middlesex (2002), was awarded the Pulitzer Prize, was shortlisted for the National Book Critics Circle Award and the French Prix Medici. The Marriage Plot (2011), his third novel to date, was a National Book Critics Circle Award finalist. First published in various magazines (The New Yorker, The Paris Review, The Yale Review, etc.), Jeffrey Eugenides's short stories were collected in Fresh Complaint in 2017. Eugenides is a fellow of the American Academy of Arts and 
Sciences and was elected to the American Academy of Arts and Letters in 2018. He has taught creative writing at both Princeton and NYU.

2 In September 2018, Jeffrey Eugenides was a guest of the Festival America in Vincennes, France, where he kindly agreed to discuss his work with me. The interview was conducted by email between May and October 2020 .

3 Jérémy Potier: The first chapter of The Virgin Suicides was first published as a short story in The Paris Review. Your collection of stories, Fresh Complaint, includes an alternative ending for Middlesex, whose early chapters also appeared in magazines. Mitchel Grammaticus, from The Marriage Plot, is the protagonist of "Air Mail" (later reprinted in Fresh Complaint). Do the stories serve as experimental sites for the novels? Do you tend to work with ideas, motifs and characters first?

4 Jeffrey Eugenides: There's no method to my madness. Yes, the first chapter of The Virgin Suicides was published in The Paris Review, but I always knew it would become the first chapter of a novel. "The Oracular Vulva" isn't an alternative ending for Middlesex but an outtake from an alternate version of the book. Early on in the composition of that novel, I had two separate manuscripts, one narrated by Cal Stephanides, who narrates Middlesex, and another written in the third person. I had about 150 pages of each potential book and then went on to write and finish only one of them. I managed to use bits of the third-person version in Middlesex but most of it had to be discarded. So you could say that I saved "The Oracular Vulva" from oblivion in order to ease my pain. Finally, by the time I wrote The Marriage Plot, I had forgotten that my story, "Air Mail," had as its protagonist one Mitchell Carambelis. He's the same character as the Mitchell Grammaticus in The Marriage Plot, so when I put the story collection together, I tidied up that discrepancy and gave them the same last name.

5 In general, I work with ideas first, though not "ideas" but storylines. To adjust William Carlos William's famous dictum: "No ideas but in stories." That would be my motto.

6 JP: The Virgin Suicides is very much an experiment on voice, Middlesex focuses on building up an intricate plot, while The Marriage Plot is distinctly influenced by the realist tradition. Many novelists of your generation have followed a similar path, moving from experimental writing towards a renewed engagement with the realist form. How do you articulate these two trends? But perhaps you would like to comment on the use of the word "realist" first?

7 JE: To my mind, all of my books fall into the "realist" camp. Though the voice of The Virgin Suicides is unusual, its origin impossible to explain, nothing that happens in the book defies the laws of physics or departs from "reality." The atmosphere of the book may seem exotic and feverish, but everything that happens could happen. In fact, many things in the book that people think I made up actually occurred during my childhood.

8 With Middlesex, the idea was to write a novel about an intersex person without resorting to mythology or anything smacking of a fairy tale, as Virginia Woolf did with Orlando. I wanted to be as accurate as I could about the medical and genetic facts of my narrator's life. The book begins with Cal trying to reconstruct his grandparents' lives. In the telling of that story, he can be fanciful, but he departs from the plausible. From there the book becomes more naturalistic, more of a modern psychological and social novel, as it goes along.

9 To me, the world we live in is as fantastical as anything I might dream up. I want to do it justice. I don't think reality is insufficient or needs a boost to be fascinating or 
worthy of examination. Depending on my mood, my writing can become imbued with different qualities that might seem more or less "realist," but in the main I'm not a fantasist and few of the writers I love are either. Of course, having said that, you never know. I do sometimes have outlandish fictional ideas. But no matter what I write, the imperative for me is to convince myself that the story I'm writing is true, that it happened, or could have happened. It needs to feel credible, first to me and then, with luck and effort, to the reader. Otherwise, I give up on it.

JP: In The Virgin Suicides, an indeterminate, collective "we" narrator incarnates the consciousness of a whole community. In Middlesex, Cal smoothly moves from female to male gender, and although (s)he is fundamentally a first-person narrator, the novel benefits from a degree of omniscience. What is so fascinating about these multi-layered -indeed, impossible-voices? Do they amount to a way of resisting the tyranny of a single and consistent voice?

11 JE: I've never had a single, consistent voice as a writer. The perennial writing advice goes: "Find your voice." But what if you can't? What if you don't have a fundamental, unitary voice? Are you done for? I don't think so. It seems more likely that a novelist might possess a multiplicity of voices. In my own case, I have created a different voice for each of my books. Now that I'm getting older, I have certain modes that I can work in; and some of them are beginning to feel more like a single, consistent voice. But it's all ventriloquism, when you come down to it. Fiction is the only place where you can unleash a voice that comes out of nowhere. Whose origin is mysterious, even potentially inhuman, or suprahuman. Fiction, the Bible, and other religious texts. That's a great freedom. It would be a shame not to avail oneself of it.

12 JP: Middlesex is informed by the metaphor of the silkworm, which evokes both metamorphosis and transience, but also fiction writing, indeed an art of weaving. In your novels, you do weave together a great variety of discourses: both historical events and everyday incidents in Middlesex; rumors and testimonies, myths and written documents in The Virgin Suicides. Is this sense of hybridity meant to challenge linear, univocal discourses? The discourse of history, in particular, tends to be put into perspective in Middlesex: “The governor didn't say it; the newspapers didn't say it; the history books still do not say it, but I, who watched the entire thing on my bike, saw it clearly: in Detroit, in July of 1967, what happened was nothing less than a guerrilla uprising" (Eugenides, 1993 248).

13 JE: That's a hard question to answer. Obviously, it would be absurd for me to say that a book like Middlesex doesn't champion the notion of hybridity. At the same time, precisely because of books and films like Middlesex, the concept of hybridity has become a little too trendy for my taste. It's wielded politically now in an effort to oppose tradition or classicism, wielded often cavalierly and without any appreciation for history other than the notion that everything that exists now, having arisen from existing power dynamics, must be bad. I don't want to throw the baby out with the bathwater, however. The bathwater, fine, get rid of it. But not the baby.

Middlesex is both a classical novel and a revolutionary or disruptive one. At least that was my aim. The hybridity it reveals is, in essence, an ancient one. Often, we have to retrace out path to find a way out of the thicket of the present.

As far as the lines you quote go, they touch on my commitment to truth and realism. What Calliope sees on her bike during the Detroit riots is not a riot but a rebellion. As I write this today, another rebellion is taking place in Minneapolis and many other cities 
in the U.S. Most Detroiters who are African-American see it that way and Cal, with his partial omniscience, sees it that way too.

JP: I am particularly interested in the way you handle details. In The Virgin Suicides, specifics tend to create a sense of polyphony-they allow for other storylines, other ways of perceiving the same events, other lives into the main narrative. In the end, they put to the fore of the story the collective process of reconstructing a specific time and place. Is this use of details a way of "doing justice" to the world we live in and, specifically, the world you grew up in?

JE: Saul Bellow, in imagining death, said that "the pictures stop ${ }^{1}$." In a sense, death is just that simple. As soon as we become conscious, we begin recording our lives visually. If you happen to be a writer, that mental video footage becomes the raw material you draw on to write your books. Much of the compulsion to write the stories stems from a desire to fix experience, to keep it from passing away, and, by fixing it, to examine it minutely in an effort to figure out what it was all about. For me, "doing justice" to the world involves paying attention to its specificity, all the details that make up a place, a neighborhood, a family, or a person. Edward Abbey called the earth "the only paradise we will ever know, the only paradise we ever need, if only we had eyes to see." I agree.

JP: The next question builds on a quote from The Marriage Plot: "He looked up at all the lighted windows along the river's arc. He thought of all the people going to sleep or reading or listening to music, all the lives contained by a great city like this, and, floating up in his mind, rising just above the rooftops, he tried to feel, to vibrate among, all those million tremulous souls" (Eugenides, 2011 161). How does this impulse to connect with multiplicity respond to the suburb, where everything appears be so univocal? But perhaps there is more than meets the eyes in the suburbs?

JE: I think there's more that meets the eyes. When I started writing, I didn't think the suburbs were a worthy setting. The suburbs where what I knew about, though. And as soon as I did set my fiction there, I found that I knew a lot about what went on. I was still largely a stranger to myself, but I knew who lived in the houses in my neighborhood, what the marriages were like, who was happy, who was unhappy, who drank too much, which kid was ridiculed and which kid was envied. So, I wrote about that. Surprisingly to me, when I did, people recognized their own towns and villages in my suburban stories. The route to the universal, it appears, makes local stops.

JP: When Greek-born Lefty and Desdemona first approach American ground, they are faced with the monumental skyline of New York and, later, with "the swirl and hubbub" of the city of Detroit (Eugenides, 2002 76). A generation afterwards, their children approach America through a different landscape which, compared with the city, reputedly lacks reliefs and monuments. I am interested in the way you, as a writer, have approached suburban Michigan. How does that differ from writing the city?

JE: Most of my work deals with both the city and the suburbs. I was born in Detroit and grew up in a suburban house just a few blocks from the Detroit city limits. The friction between those two worlds, one comprising a great industrial American city and the other an affluent small town that tried to wall itself off from that city and its inhabitants, generates a good deal of my work. I can't write about Detroit without writing about Grosse Pointe and I can't write about Grosse Pointe without writing about Detroit. They depend on each other, like black and white, quite literally in this instance. 
The street we lived on was only five or six blocks from Detroit, and the demarcation between city and suburb was a physical one: a canal separated them like a moat. I grew up in this borderland between city and suburb. On one side of the canal, white people. On the other, black people. Tremendous differences in terms of race, culture, income, you name it. Antagonism. Animosity. But also day-to-day toleration for each other. In addition to that, my own neighborhood of Grosse Pointe Park contained all kinds of people. There were the Mafia families who lived on our block, the Toccos and the Corados and the Zurellis. There were Egyptian, Polish, Dutch immigrants. My mother was a Southerners, from Kentucky, and my grandparents were Greeks from Asia Minor.

And, right next door to all this activity, which wasn't "univocal" in the least, was Detroit, this massive and massively significant American city. My parents grew up there and as a family we were still connected to the city. It was the constant traversing back and forth across the boundary line that made me so interested in the shifting nature of identity, I think. It also acquainted me with the key realities of America that continue to feed my fiction.

JP: In your novels, grandparents are often sent off to basements (Mrs. Karafilis in The Virgin Suicides) or attics (Desdemona and Lefty in Middlesex). Is that a comment on the fate of history in the American suburb? In both novels, you insist on the role of chance and coincidence, rather than causality, which is more readily associated with the discourse of history. One of your narrators speaks of an "obsession with chance and fate" (Eugenides, 2002 317)... Yet, your narrators do tend to create alternative historical discourses.

JE: In this case, it's because my grandmother really did live in the basement. So did I as a teenager. And so did my uncle. Many of my relatives seem to have lived subterranean existences. I have joked, regarding Old Mrs. Karafilis, that she represents one way to deal with one's ethnic heritage: keep it down in the basement. People liked that character a lot, though. People always asked me about her. And so, in Middlesex, I let her come upstairs and take over the house. are akin to ragmen collecting fragments of the past. In doing so, they manage to provide the neglected, self-effacing neighborhood of Grosse Pointe with a sense of memory. Would you like to comment on this archaeological way of approaching the memory of the suburbs?

27 JE: I don't think the collecting and cataloguing of artifacts of the Lisbon sisters has to do with the suburbs at all. It has to do with the nature of suicide. Those who have been left behind when a suicide occurs are left with questions. Why did the person do it? Was it there anything they could have done to prevent it? Survivors of suicide try to answer these questions by piecing the dead person back together, sufficiently, at least, to be able to mourn them properly. I think that's what the boys are trying to do.

JP: The narrator of Middlesex eventually realizes that all the ordinary objects of her/his life can stretch back in time and disclose stories provided that she/he looks closely enough. Interestingly, the revelation comes with a mulberry tree-which, again, silkworms feed on (Eugenides, 2002 396-397). Like Poe's purloined letter, which you mention in one of your short stories, meaning is hidden in plain sight (Eugenides, 2017 229). In The Virgin Suicides, one of the characters attempts to save her grandmother's collection of rare orchids by feeding them with "an eye-dropper filled with what looked 
like milk" (Eugenides, 1993 109-110). Do you mean to imply that a sustained effort of attention can be a way to both disclose and safeguard what is usually so easily overlooked?

JE: This goes back to what I said earlier about literary detail and specificity. I often have the feeling that if I don't write about the major events in my life, if I don't record them faithfully, I will have experienced them for naught. It will be almost as if they never happened. It's as though I have to live my life twice, once in reality and the second time in fiction. Otherwise how can I be sure that I did live? That I was alive? And that everything I saw, felt, touched, and loved won't disappear? It all will, of course, but the literary impulse arises in opposition to that inevitability.

JP: In The Virgin Suicides an important site of memory is the condemned elm tree in the Lisbons' garden. The "Liberty Oak" that appears at the end of The Marriage Plot also fosters a meditation on memory: "Halfway through the text, Mitchel realized that the 'Liberty Oak' the marker commemorated had died of blight years ago, and that the tree growing there now was a mere replacement, a variety more resistant to insect infestation but less beautiful or big. Which was a history lesson in itself. It applied to so many American things" (Eugenides, 2011 393). The relationship that you draw between (dead) trees and memory is intriguing. Would you like to comment on the recurring motif?

JE: The real impetus for writing The Virgin Suicides was something I was unconscious of at the time. While I was growing up, Detroit lost more than half its population. Great swaths of the city became vacant. Landmarks and major buildings were condemned and demolished. On top of that, almost all of the wondrously beautiful elms trees in the city died off. Detroit was once known as "The City of Trees." Whenever I go back now the absence of those cathedral elms fills me with the most acute sense of pain and loss.

The sheer fact of growing up in a city succumbing so speedily to the forces of decay and entropy taught me early on about the impermanence and ephemerality of things. That, and a strain of melancholy in my blood, made me attentive to the vanishing of things, and imbued me with a tendency toward nostalgia. That's not getting any better as I get older. It's much worse now. I lived in the past even when I was young, so imagine what I'm like now. Despite that, I'm listening to Billie Eilish's "My Future" as I type this, which keeps me feeling young. The suicides of the Lisbon girls came from the strong sense I had as a boy that nothing lasts. Writing is a hedge against that. A weak one, maybe, but it's enough for me. I haven't lived in Detroit for over forty years now, but I spend almost every day there in my mind and memories.

JP: The practice of drawing on commonplace landmarks to disclose the memory of ordinary American men and women can be reminiscent of the works of Walt Whitman or, more recently, of William Carlos Williams and Robert Smithson. At the end of The Virgin Suicides, you resort to the image of an "overexposed photograph" (Eugenides, 1993 243) to describe the naked suburban landscape, an image Robert Smithson uses as well in "A Tour of the Monuments of Passaic, New Jersey" (1967). Do you feel a connection to these artists, who also explored the memory of nondescript landscapes such as suburbs and small industrial towns?

JE: I don't know the work by Smithson that you mention. But I'm always moved by desolate urban landscapes. As it so happens, I spent a fair amount time in Paterson not long ago. I was fascinated with its waterfalls, which I hadn't known about. They're still there and still quite beautiful, though the city has encroached upon them in every 
direction. There's a park by the falls and a monument to William Carlos Williams, and a mural. It made a big impression on me. The red brick factories were built right up to the edge of the falls to take full advantage of their hydroelectric power. Absolutely no thought was given to creating a buffer zone between mercantile activity and nature. And yet the falls themselves remain majestic. So, you have two halves of the American story right there: the heedless rush for profit-making and industry on one hand and, on the other, a natural landscape so vast and wild that it appears unable to be contained. And you can see all that from a bench no more than twenty feet from the parking lot of the overlook, which happens to be a National Park.

JP: "All those flowers. All that dust" (Eugenides, 2002 51). The quote comes from The Virgin Suicides. The narrative is obviously informed by a tender touch of nostalgia. There is something particularly fascinating about the way the once semi-pastoral setting of the suburb gradually turns into a valley of ashes. Jonathan Franzen also portrays the suburb as a declining setting in The Corrections (2001) and John Cheever's sensuous gardens tend to wither away in the stories and novels of the 1960s. How do you relate to the idea of the pastoral today?

JE: Though I grew up in the suburbs, I've lived in cities for the past forty years. Providence. San Francisco. Berlin. Chicago. And New York. The pastoral isn't something I've had much experience with.

JP: Here is another quote from The Marriage Plot: "The window gave onto a view of dovegray roofs and balconies, each one containing the same cracked flowerpot and sleeping feline. It was as if the entire city of Paris had agreed to abide by a single understated taste. Each neighbor was doing his or her own to keep up standards, which was difficult because the French ideal wasn't clearly delineated like the neatness and greenness of American lawns, but more of a picturesque disrepair. It took courage to let things fall apart so beautifully" (Eugenides, 2011 136). Letting things fall apart beautifully is one of your achievements in The Virgin Suicides. In fact, decline is arguably a condition for art in the novel. Is there aesthetic potential in decline?

JE: Oddly enough, though decline and disintegration have figured strongly in my books, by temperament I'm a classicist, that is, someone who attempts to preserve the past in as orderly and lasting way as possible. Most days, my chief impulse is to expend my energy in opposing the force of entropy, especially when it comes to literature. Whatever my aesthetic program is, it has a conservative streak. I emphasize the root of the word here: to conserve. To keep safe. To protect what you've been given and not squander it.

JP: In the Preface of The Marble Faun, Nathaniel Hawthorne laments the want of romantic ruins in America: "No author, without a trial, can conceive of the difficulty of writing a romance about a country where there is no shadow, no antiquity, no mystery, no picturesque and gloomy wrong, nor anything but a commonplace prosperity, in broad and simple daylight, as is happily the case with my dear native land. [...] Romance and poetry, ivy, lichens, and wall-flowers need ruin to make them grow" (Hawthorne VIII-IX). Surely the situation has changed for American writers today? Detroit hardly distinguishes itself for its want of ruins...

40 JE: Yes, exactly. If Hawthorne had lived in Detroit, he'd be singing a different tune.

41 JP: Saying "There used to be a tree, there" is also a way to conjure up a common sense of memory. As a matter of fact, your characters often seem to recognize their belonging 
to a community through grief. Mourning the Lisbon sisters, in particular, is a way for the inhabitants of Grosse Pointe to build up a common narrative, possibly a myth, that allows them to reconstruct the declining community. I am thinking for instance of the mock-epic passage when the fathers of the community struggle to uproot the fence that killed Cecilia. Attempting to reconstruct a sense of community through grief strikes me as a very American notion. To what extent does The Virgin Suicides relate to the failed ideals of the nation? You evoke those ideals in "Great Experiment" (Fresh Complaint), in a passage strikingly reminiscent of the last pages of The Great Gatsby.

JE: With "Great Experiment" I was having a conversation with De Tocqueville's Democracy in America, which I had been reading at the time. At the moment, there's a strong impulse among a lot of people to disavow anything of worth in the American experiment and, instead, to contend that the nation was rotten at its very core, right from the beginning. Before the beginning. One thing I liked about Obama was his insistence on exhorting Americans to live up the ideals of the country and to seek to make a more perfect union. I don't think any country can prosper with a national narrative that is entirely negative. "Great Experiment" does describe how far the United States has strayed from its ideals and how far Americans are from achieving "equality of condition." But the story's bitterness derives from its perception that the foundational ideals have been so badly betrayed. The philosopher Richard Rorty's book Achieving Our Country made a big impression on me. In that work, Rorty says that it's the novelist's job to create a national narrative. Not politicians or Civil Rights leaders or religious leaders, but novelists. They're the one who have to create fictions that allow citizens to have a collective national identity and purpose. Something everyone can believe in and work toward and be united by. "Great Experiment" is at once a lament for America and an exhortation to find in its beginnings a way to begin again.

JP: Houses are essential structures in your work. From Walden to Gatsby's estate, they tend to function as utopian alternatives in much American fiction. Of course, the secluded Lisbon house lies at the heart of the intrigue in The Virgin Suicides. But there is also the boys' tree house, where the grown-up narrator attempts to recreate a mythical past. The is reminiscent of Huck's wooden raft, which serves as a counter-site where the heroes momentarily manage to escape the historical necessities of living on the shore, among adults. The boys' wooden house, nested in the declining semi-pastoral setting of the novel, strikes me as a site of playful recreation amid a river of green. How do you relate to this possible trend in American fiction?

JE: I have a theory that growing up in a stable house endows a person with psychological stability. Living in a house (and it doesn't have to be a house, it could be an apartment), the experience of dwelling inside a solid structure whose rooms are all known to you, where every sound can be identified and where you know who is where and what's going on in each room just by the vibrations that reach your ears, endows a person with the sense of security necessary for risk-taking and invention later in life. I love books that are about houses. All of my books are about houses, on some level, not just The Virgin Suicides but Middlesex, too, and also The Marriage Plot. Houses are the stages where human life is acted out. When I'm writing something, I always have in mind a particular house or apartment, so that I can see where the characters are, and how they move around in it. I don't think it has anything to do with the pastoral. The domestic, rather. But, as I said, for me the domestic is the dramatic. 
JP: I would like to conclude this interview with a more general question about literature. "Emotions, in my experience, aren't covered by single words. I don't believe in 'sadness,' 'joy,' or 'regret”' (Eugenides, 2011 217). This quote from Middlesex seems to herald one of the thematic concerns later developed in The Marriage Plot: the idea that love, in particular, might be a literary invention. The novel opens with a quote by François de La Rochefoucauld: "People would never fall in love if they hadn't heard love talked about." Does that also imply that reading fiction allows us to live fuller, deeper lives in inventing what would otherwise be left unnamed, tied to our biological determinisms?

JE: It might also mean that reading fiction, or at least romantic fiction, creates in us desires we can't fulfill. My novel The Marriage Plot attempts, like much of the fiction I most revere, to emancipate the reader from his delusions. How do we learn to love when love has been discredited? I take it on faith that love lies at the center of a successful human life. Love is the most important, worthwhile, enlightening, and enlarging experience that can happen to us. But that only happens when love exists apart from our ideas about love. And by that I mean when it's not about dream but reality.

\section{BIBLIOGRAPHY}

BELLOW, Saul. Ravelstein. New York: Viking, 2000.

CHEEVER, John. Bullet Park. New York: Alfred A. Knopf, 1969.

CHEEVER, John. The Stories of John Cheever. New York: Alfred A. Knopf, 1978.

CHEEVER, John. The Wapshot Scandal. New York: Harper \& Row, 1964.

EUGENIDES, Jeffrey. Fresh Complaint. New York: Farrar, Straus and Giroux, 2017.

EUGENIDES, Jeffrey. The Marriage Plot. New York: Farrar, Straus and Giroux, 2011.

EUGENIDES, Jeffrey. Middlesex. New York: Farrar, Straus and Giroux, 2002.

EUGENIDES, Jeffrey. The Virgin Suicides. New York: Farrar, Straus and Giroux, 1993.

FRANZEN, Jonathan. The Corrections. New York: Farrar, Straus and Giroux, 2001.

HAWTHORNE, Nathaniel. The Marble Faun; or, The Romance of Monte Beni, vol. 1. Boston: Ticknor and Fields, 1866.

POE, Edgar Allan. "The Purloined Letter." 1844. Complete Stories and Poems of Edgar Allan Poe. New York: Doubleday, 1984, p. 125-138.

RORTY, Richard. Achieving Our Country. Cambridge, MA: Harvard University Press, 1998.

SMITHSON, Robert. "A Tour of the Monuments of Passaic, New Jersey." 1967. Robert Smithson: The Collected Writings. Ed. Jack Flam. Berkeley: University of California Press, 1996, p. 68-74. 


\section{NOTES}

1. "He had, however, asked me what I imagined death would be like-and when I said that the pictures would stop he reflected seriously on my answer, came to a full stop, and considered what I might mean by this. No one can give up on the pictures-the pictures might, yes they might continue. I wonder if anyone believes that the grave is all there is. No one can give up on the pictures. The pictures must and will continue" (Bellow 222).

INDEX

Subjects: Reconnaissances

\section{AUTHOR}

\section{JÉRÉMY POTIER}

Université Toulouse-Jean Jaurès 